\title{
Financing the Cost of an Eighteenth-Century Scottish Estate
}

Le financement du coût d'un domaine écossais du XVIII siècle

\section{Clarisse Godard Desmarest}

\section{(2) OpenEdition}

\section{Journals}

Electronic version

URL: https://journals.openedition.org/etudesecossaises/707

DOI: 10.4000/etudesecossaises.707

ISSN: 1969-6337

\section{Publisher}

UGA Éditions/Université Grenoble Alpes

\section{Printed version}

Date of publication: 15 April 2012

Number of pages: 145-163

ISBN: 978-2-84310-223-3

ISSN: 1240-1439

\section{Electronic reference}

Clarisse Godard Desmarest, "Financing the Cost of an Eighteenth-Century Scottish Estate", Études écossaises [Online], 15 | 2012, Online since 15 October 2013, connection on 11 April 2023. URL: http:// journals.openedition.org/etudesecossaises/707 ; DOI: https://doi.org/10.4000/etudesecossaises.707

All rights reserved 


\section{Financing the Cost of an Eighteenth-Century Scottish Estate}

In the middle of the seventeenth century, numerous estates belonging to the aristocracy were in a precarious situation due to the heavy taxes of the Interregnum, the high cost of the army and the weak commerce. However, innovations took place after the Restoration of 1660 when the classical style of the Renaissance penetrated into Scotland. Country mansions were the prime vehicle for the introduction of classicism since few public or church buildings were erected, due in part to the absence of the Court and to the poverty of the burghs. The Scottish nobility increasingly felt that the medieval and Renaissance old tower houses of their families were unsuitable and had to be transformed to follow the changing lifestyle which required increased privacy and space. In addition to Holyrood Palace in Edinburgh, Glamis, Thirlestane, Panmure and Drumlanrig were transformed by powerful aristocrats with prestigious lineage - the earl of Strathmore and Kinghorne, the duke of Lauderdale, the earl of Panmure and the duke of Buccleuch. In the late seventeenth and early eighteenth centuries, wholesale reconstructions were carried out at Hamilton and Dalkeith Palaces by the duke and duchess of Hamilton and by the duchess of Buccleuch. In their diaries and correspondence, John Macky and Daniel Defoe, who had both visited Scotland in the 1720s, were not without mentioning the transformation of these grand estates. To Daniel Defoe, the apartments of Hamilton Palace - where James Smith was involved in building an extensive scheme between 1684 and 1700 - were "very noble, and more fit for the Court of a Prince, than the House of a subject" 1 and the house was comparable to Chatsworth, the seat of the duke of Devonshire. However, only the most wealthy and influential Scots could indulge in such architectural pursuits because of cost constraints and of the unsecure economic and political situation.

1. Daniel Defoe, A Tour Thro' the Whole Island of Great Britain. Divided into Circuits or Fourneys. Giving a Particular and Entertaining Account of Whatever Is Curious, and Worth Observation, vol. IV, London, Printed for S. Birt, 1748 [1724], p. 130. 
After the 1715 Jacobite rebellion and from the 1720s onwards, a growing number of Scottish landowners who belonged to the gentry and had been on a Grand Tour on the continent became involved in architectural projects and built villas. The Scottish architects of the eighteenth century among whom were William Adam (1689-1748) and his sons John (1721-92) and Robert Adam (1728-92) answered the demand for elegant country houses with sophisticated interiors and set in designed landscapes. The Adam family was involved at Culzean Castle and Hopetoun House which both answered the need to achieve social recognition through a grand house. John G. Dunbar has highlighted the increasing influence of English taste as a result of the Act of Union $(1707)^{2}$ and the loss of the distinctive national identity of Scottish architecture with the developments of industry, agriculture and trade soon after the Forty-five jacobite rebellion. The general rise in prosperity created a great upsurge of building activity and gave architects new opportunities in North and South Britain. As the economic power of Scotland increased country houses and villas were built by the "nouveaux riches" (lawyers, merchants, soldiers) enriched by their colonial adventures. However in the 1980s, several architectural historians, Miles Glendinning, Ranald MacInnes and Aonghus MacKechnie, challenged John G. Dunbar's view and analyzed Scottish architecture from a Scottish perspective. ${ }^{3}$ Although the Scottish landed classes were undoubtedly part of the British unitary nobility, the architecture of their houses retained features of national expression exemplified in the castellated houses of Robert Adam which echo the architecture of the palaces of the vernacular Scottish Renaissance.

After the Union of 1707, many landowners who perceived the need for improvement, if Scotland was to compete with England, participated in the debates of the Enlightenment and carried out innovations on their estates. They understood that the more lavish aspects of country house living had to be supported by things that made money-primarily the activity on the estate. The development of the classical country house and its designed landscape and the "revolution of manners" went hand in hand with the agricultural improvement of the estates on which they depended and to a lesser but increasing extent with the industrial development of the land - mainly through coal extraction. The direct ties between the estate and the house allowed larger improved estates to finance bigger

2. "Sir William Bruce, James Smith and the elder Adam, were content to transpose current English architectural themes into Caledonian idioms [...]." John G. Dunbar, The Historic Architecture of Scotland, London, Batsford, 1966, p. 17.

3. Miles Glendinning, Ranald MacInnes and Aonghus MacKechnie (eds), Building a Nation: The Story of Scotland's Architecture, Edinburgh, Canongate, 1999. 
houses. With the massive costs of construction and of living, landowners made use of all the resources available to them and took advantage of the spread of improvement and of the increased wealth in Scotland in the 1770 s. The resources ranged from rental and estate incomes to sinecures from political office, colonial income and credit. This study focuses on how successful the exploitation of the land was to respond to the increased costs of lifestyle and whether there needed to be other sources of income in addition to the landscape - something which would mark a radical change in both the economy and society of Scotland. This essay assesses the cost of typical Scottish country houses and of the aristocratic lifestyle that accompanied them in this period and compares it with the various sources of income that could be gained by landowners.

Country houses would have been very obvious and significant features in the eighteenth century rural landscape which was still relatively unbuilt. Scotland had a population of about one million people in the early eighteenth century so the country house and its estate must have seemed extensive and powerful in a rural country. It clearly represented the wealth and power of the landowner as castles did in the centuries before.

The concern for status was clearly reflected in the amounts that were spent. Post-Restoration Scottish society was driven by conspicuous consumption. Status reflected spending and social status was reached through the possession of goods. The country house was a center of display, a symbol of wealth and political clout and celebrated the family history. At the end of the seventeenth century, the third earl of Strathmore and Kinghorne acknowledged his wish to create a rich decor for Glamis:

I have brought things of great value for the furniture of my houses I had saved many a pond and pennie but I acknowledge a great dale of weakness in my humour that way inclining to be verie profuse upon all things of ornament for my houses as I have been upon building. ${ }^{4}$

Visitors assessed the cost of the country houses, which translated to status. The painting collection of the earl was praised by John Macky for whom it contained the best pictures he ever saw, among which were the pictures of Queen Mary of Modena, the Pretender's mother, and of the Duke of Lauderdale by Sir Peter Leley. ${ }^{5}$ At Hamilton Palace, the paintings

4. A. H. Millar, The Book of Record. A Diary Written by Patrick, First Earl of Strathmore, and Other Documents Relating to Glamis Castle, 1684-1689, vol. IX, Edinburgh, Scottish History Society, 1890, p. 32.

5. John Macky, A Journey through Scotland. In Familiar Letters from a Gentleman Here, to His Friend Abroad. Being the Third Volume Which Compleats Great Britain. By the Author of The Fourney thro' England, London, J. Pemberton \& J. Hooke, 1723, p. 141. 
hanging in the great gallery fascinated many visitors on their arrival on the first floor. Some of them were bought by the first duke of Hamilton (1601-49) and remained in the gallery throughout the eighteenth century. The collection was in keeping with the status, the power and the wealth of a family related to the Stuarts. In the recollection of his visit, Thomas Pennant mentioned family portraits by Van Dyck and a wedding celebration by Paulo Veronese. ${ }^{6}$ John Lettice was also charmed by a portrait by Van Dyck ${ }^{7}$ while John Macky had been impressed by a depiction of the Marriage at Cana by Tintoretto. ${ }^{8}$ A painting by Rubens, "Daniel in the Lions' Den", attracted the attention of Thomas Pennant, John Lettice ${ }^{9}$ as well as the English Poet William Wordsworth who visited the palace in 1801. The latter devoted a sonnet to the painting entitled "Picture of Daniel in the Lions' Den at Hamilton Palace" which was published in 1835 in Yarrow Revisited and Other Poems ${ }^{10}$ Painting collections provided a showcase for grand family homes.

The building of a large country house required massive amounts of capital and the cooperation of many different trades and professions. Money was required to finance building, collecting, commissioning portraits and furniture. In the eighteenth century, landowners paid for the architect to draw plans and to supervise building schemes. In general, the latter paid for building materials and for the wages of journeymen. The timber necessary for scaffolding or wainscoting was imported from Norway and the Baltic Sea via Dundee, Leith or Glasgow because Scotland's timber resources were scarce during most of the eighteenth century. The vast majority of the country houses built in Scotland were of fine ashlar and the stone necessary for their construction came from local quarries. However, the marble which was appreciated by the most wealthy was imported from the Low Countries. For Thirlestane, the property of the first duke of Lauderdale (1616-82), Charles II's powerful minister and a vice-roy of Scotland from 1660 to 1680, the architect Sir William Bruce brought materials from Holland such as grey and black marble. ${ }^{11}$ The castle depicted by John Slezer c. 1680 shows an elegant entrance platform with slabs of black and white marble. ${ }^{12}$ In the accounts of November 1737

6. Thomas Pennant, A Tour in Scotland and Voyage to the Hebrides, vol. I, London, Benjamin White, 1776, pp. 139-140.

7. John Lettice, Letters on a Tour Through Various Parts of Scotland in the Year 1792, London, T. Cadell, 1794, pp. 51-2.

8. Macky, op. cit., p. 284.

9. Pennant, op. cit., p. 139. Lettice, op. cit., p. 51.

10. William Wordsworth, The Poetical Works of William Wordsworth, vol. V, London, Edward Moxon, 1837, p. 166.

11. National Archives of Scotland (NAS) GD28/427. Bill of May 14th, 1671.

12. John Slezer, Theatrum Scotiae, London, Printed by John Leake for Abell Swalle, 1693, plate 57. 
for materials used at Yester House, a bill for marble alone amounted to over $£ 346 .{ }^{13}$ Marble of a different colour was ordered for the chimneys of each of the reception rooms of the house between April 1734 and August $1737 .{ }^{14}$ A particularly rich white marble chimneypiece with caryatids was ordered for the red drawing-room of Hopetoun House in 1755. It was carved by Michael Rysbrack (1694-1710), a Dutch artist, after a design by Robert Adam and testifies to the second earl of Hopetoun's refinement. Its cost of £600 was very high. ${ }^{15}$

Some additional cost resulted from the fact that some of the best Scottish artists and craftsmen of the time were involved in the building and the interior decoration of the houses. The accounts of masons, slaters, estate wrights and carpenters show the amount spent on building. At Hamilton Palace, William Morgan, a sculptor who initially settled in London and who worked at Holyrood chapel in 1688, was commissioned for the panelling and for various rich carvings in the state apartment. An account of March 13th 1700 drafted by the duchess Ann's secretary and signed by her ${ }^{16}$ lists various works done at Hamilton, such as the great wooden balustrade of the staircase situated in the north-west tower of the palace and the mouldings, cornices, decorative friezes and chimneypieces of the state rooms. This single bill amounts to a total of over $\mathcal{E} 141$. The decoration of the east wing of the palace was unfinished at the death of the duchess of Hamilton and William Adam was commissioned by the fifth and sixth dukes of Hamilton in the 1740s to decorate the interior. The architect, who relied on a variety of craftsmen for his various building sites, then chose Thomas Clayton, a gifted plasterer responsible for the gold and white stucco ceiling of the palace. At House of Dun situated in Montrose and at Yester House in East Lothian, William Adam worked with the stuccoist Joseph Enzer in the 1720s and 1740s. Although no direct account for the plasterwork at Yester seems to survive, ${ }^{17}$ it must have represented a significant amount of money for the marquess of Tweeddale. The plasterwork of the salon at Dun is particularly impressive. It shows a bas-relief of Mars above the fireplace of the north-east wall and Neptune on the opposite wall. This elaborate stucco decoration

13. National Library of Scotland (NLS) MS 14551/57.

14. NLS MS 14551/59. The total amount for chimneys amounted to over $£ 86$.

15. Katharine Eustace, "Robert Adam, Charles-Louis Clérisseau, Michael Rysbrack and the Hopetoun chimneypiece", The Burlington Magazine 139.1136, 1997, p. 748.

16. RCAHMS Lennoxlove House Ltd. SCRAN 000-000-599-072-C. "The carver bill for carved work done for her Grace the Duches of Hamilton."

17. There is evidence that Joseph Enzer worked at Yester House between 1736 and 1739 for the craftsman wrote in his account book: "I Came again to Yester and Began to Work on Mund, ye, 16th August, and With Me Philip Robertson My Aprentice." NLS MS 14666/1. 
testifies to the Jacobite sympathies of the owner of the place, a cousin of the earl of Mar, a well-known Jacobite, and promotes the hope of restoring the legitimate monarch. The war god Mars was represented with his foot resting on a shield bearing the French and Scottish emblems, the lily and the lion. The masks of Bacchus and Apollo, the hunter god and poet, appear on the stucco ceiling and the trophies of arms and armour and festooned urns filled with fish of the overdoors recall peace and plenty. This plasterwork forms part of the stucco decoration carried out by Joseph Enzer at the house and for which he received $£ 216$ in 1742. Family accounts number expensive bills for house painting. The most famous workshop of the eighteenth century was that of James Norie (1684-1757), an Edinburgh house painter specialised in overdoors who supplied paintings for numerous William Adam interiors like Arniston, Hopetoun, Mavisbank or Yesterand whose office was very popular in Scotland in the 1730 s and 1740 s.

Interior furnishing revealed the ambition of the owners. At the end of the seventeenth century, the grandest estates had wrights on site who were in charge both of panelling the rooms and making the state bed and various other pieces of furniture. However the furniture, silver and works of art of the wealthy Scottish nobility were often imported from Holland. They came mostly from England in the eighteenth century when aristocrats turned to London furniture-makers for refined pieces of ornament. The remarkable collection of Chippendale furniture at Dumfries House, situated in Ayrshire and built by John and Robert Adam between 1754 and 1758 for the fifth earl of Dumfries (1699-1768), is reckoned to be the most exceptional example of fine quality Chippendale furniture in Scotland. It was formed in the middle of the eighteenth century and although Lord Dumfries commissioned some Edinburgh furniture-makers like Alexander Peter, William Mathie, Robert Young and Tom Trotter, he chose a fashionable London maker for more exceptional pieces. Lord Dumfries also bought an exceptional Boulle commode for 15 guineas in 1759. ${ }^{18}$ Charles-André Boulle (1642-1732) was the famous cabinet-maker of Louis XIV. Some other rare elements of expensive French refinement could be seen in interiors. In 1785, the fifth duke of Argyll (1723-1806) commissioned a set of Beauvais tapestries representing pastoral scenes designed by Jean-Baptiste Huet and made by Sieur de Menou for Inveraray Castle, the property of the duke in the Highlands. ${ }^{19}$

18. One guinea amounts to 21 shillings. Taxation and the cost of transport discouraged the importation of French furniture during most of the 18th century.

19. The castle was built between 1746 and 1758 but the decoration of the rooms was only discussed after 1783, after the end of the American war of independence when the release of tensions 
Dutch portraits and landscapes of the Italian school by Claude Le Lorrain, Nicolas Poussin or Salvator Rosa found their way to Scotland. They were often brought to Scotland by Scots on their Grand Tour. However, the cost of such acquisitions was a matter of concern. Lord Annandale (16871730) warned his nephew John Hope of Hopetoun (1704-81), who was in Italy between 1722 and 1727, of the dangers of spending too much on works of art but could not refrain from asking him to buy several Italian master paintings for his own collection. Lord Hope chose paintings for his uncle among which were some by Giovanni Battista Benaschi (1636-88), Giaquinto Brandi (1621-91) and Giovanni Francesco Romanelli (161062) and as many as three crates were necessary for their transport by sea to Scotland. The decoration of the houses ran parallel to the creation of formal and productive landscapes which formed another source of significant expenditure. Different varieties of seeds and trees, sometimes foreign, were bought by Scottish landowners.

The rising social status of the landowner was often synonymous with new projects of construction and decoration. Less than twenty years after Sir William Bruce finished building Hopetoun House to a harmonious and elegant design, ${ }^{20}$ Charles Hope (1681-1742) carried out a new, more ambitious project for his house in the 1720 s. It was partially destroyed and rebuilt by William Adam, a then relatively inexperienced architect, the plans of whom are shown in Vitruvius Scoticus. ${ }^{21}$ This grander project for Hopetoun was to correspond to the new status of Charles Hope who had become the first earl of Hopetoun in 1703. The latter's taste and knowledge of architecture - he had been on a Grand Tour - were probably responsible for his wish to build a more fashionable house. The size of his family further explains the need for enlarging the house. William Adam kept many aspects of the Bruce design but refronted the entrance façade to accomodate a grand state apartment and built two pavilions, one on the north to contain the stables and one on the south for the library and billiard-room. He also rebuilt the quadrants, making them concave rather than convex, thus conforming to the Palladian orthodoxy. Keeping up to date with changes in taste made constant innovations necessary and required a relevant inflow to cover this expenditure.

The cost of an aristocratic lifestyle was clearly significant and visits to London placed an even larger strain on the finances of Scottish noblemen.

with France made it possible to consider a French programme of decoration. Several French artists were involved in the decoration.

20. Building contract of December 28th, 1698 concluded by Lady Margaret Hope, mother of the young Charles Hope (NAS GD45/17/769). The plan and elevation of Hopetoun House of Sir William Bruce are illustrated by Colen Campbell in Vitruvius Britannicus (plates 75-77).

21. William Adam, Vitruvius Scoticus, Edinburgh, P. Harris, 1980 [1812], plates 14-19. 
Before the Union, the Hamilton correspondence shows concern for the cost of a London lifestyle. When in London for business the third duke of Hamilton (1634-94) had a constant eye on his spending since the cost of mainting a large household in the city was high - even more so since he had to rescue his Scottish estate from debt. In 1700 the earl of Cassilis was driven to make a suggestion:

because of our king's not residing amongst us, and the great expenses many of this kingdom are at in going to Court, that a small number be chosen by his majesty to reside at Court for five or six years to represent to his majesty the state of the kingdom and advise him. ${ }^{22}$

Few Scottish peers could in fact afford to keep a permanent home in London and the necessary visits to London significantly increased the cost of living of the Scottish nobility after the Union of parliaments.

The remodelling of existing houses or the building up of new ones to fit modern taste, coupled with the money spent to finance a designed landscape and a luxurious lifestyle, increased the demand for revenues. The costs of construction and living pushed landowners to make use of all the resources available to them. These ranged from estate incomes to political sinecures, colonial income and credit.

Aristocrats and members of the mercantile and professional classes realised that the economic development of their land was paramount to finance a lifestyle of pleasure and the material competition which characterised the landed elites. In the eighteenth century, estates became viewed as resources which could be exploited for economic gain to support this new lifestyle. Landscapes were thus shaped by these rising demands. This was the first time that the cultural expressions of elite society in ashlar and in lifesyle were underpinned by economic activities. Indeed for hundreds of years the feudal estates had remained self-sufficient, based on the exchange of services. They provided feudal duties to landowners. ${ }^{23}$ However, with rents in cash replacing rents in kind in the eighteenth century, the aristocracy could increase its revenues by setting higher rents. The land was seen as providing an income rather than as constituting a collection of tenants. A shift in mindset explains that the land was no longer enough to indicate status, it was the returns that could be got from it that was of importance. Unlike in France where landowners had different lordly rights and privileges that went with their estates which secur-

22. Sir David Hume of Crossrig, A Diary of the Proceedings in the Parliament and Privy Council of Scotland, 21 May 1700-7 March 1707, Edinburgh, Bannantyne Club, 1828, p. 23.

23. Michael Lynch, Scotland: A New History, London, Barrie \& Jenkins, 1991, p. 56. 
ed extra revenues from tenants and subjects, landowners in Britain had to concentrate on landed improvements because they had fewer feudal rights than on the continent. ${ }^{24}$ When the third duke of Hamilton decided on the reconstruction of his palace he started with the offices which were moved into clean buildings. It testifies to a new perception of the estate, which was to become a well-managed and profitable enterprise.

This mindset had an impact on the landscape and on the way landowners mapped their estates. The drive to increase income from the estate could begin by improving the agricultural methods to increase yields and ultimately gain higher returns. Although from 1660 several Acts of Parliament encouraged agricultural improvement through enclosure and crop rotation, agricultural improvement only got underway on a nationwide basis a century later. The rise of food prices, of oats and barley in particular, and the expansion of a commercial market then created a strong incentive to increase production. Without denying the fact that the market stimulated the improvement, the responses of rural society - estate factors, farmers and landowners - were prominent. The main improvements were held by individuals on their estates. Debates in clubs and societies showed an interest in botany, horticulture and meteorology and landowners of the fertile eastern Lowlands were responsible for major breakthroughs. The necessary improvement of nature was justified by the philosophers of the Enlightenment: maintaining the lands in a "state of nature" was no longer seen as acceptable. Lord Kames, both a philosopher and a notable agricultural improver on the estate of Blair Drummond, criticized the old system of exploitation of the land in "runrigs" - the traditional system of cultivation - in which the common lands lay fallow. The Society of Improvers created in 1723, which numbered as many as 300 members of the Scottish aristocracy, played a key role in the experimentation and dissemination of the new methods of exploitation of the land necessary to try and maximize profit.

Landowners were conscious of being architectural as well as agricultural and industrial improvers and of participating in the transformation of their country. In his treatise The Countryman's Rudiments: Or, An Advice to the Farmers in East-Lothian, How to Labour and Improve Their Ground (1699), John Hamilton (1656-1708), second baron of Belhaven and Stenton, a famous improver, described some methods of improved farming that should be applied to the land of his fellow peers. To him, it was the duty of the landowner to improve his land for the good of the estate and

24. Jerzy Lukowski, The European Nobility in the Eighteenth Century, Basingstoke, Palgrave Macmillan, 2003, p. 78. 
the nation as a whole. ${ }^{25}$ On his estate of Ormistoun, John Cockburn of Ormistoun (1679-1758), a judge and a member of the post-Union Parliament, enclosed fields, set up crop rotation and developed linen manufacture in the village of Ormistoun in the 1740s. The initiatives of this pioneer were admired by Lord Kames. ${ }^{26}$ Archibald Grant of Monymusk (1696-1778), a judge and member of Parliament, drained the marshes of Monymusk, enclosed his lands and planted trees in the 1720s. In his Memorandum to My Son of June 28th, 1754 he detailed the returns of the sale of the trees on his estate. ${ }^{27} \mathrm{He}$ was aware of the financial manna of the various industries like weaving or mining - the village of Monymusk contained a linen factory - and after he was expelled from the House of Commons in 1732 because of his involvement in the frauds on the Charitable Corporation, he stepped up his efforts to secure a comfortable profit from his estate in order to recover the fortune necessary to support his lifestyle. Individual initiatives in the textile industry, which flourished from the 1730 s to the 1740 s, were backed up by public bodies like the Board of Trustees for Fisheries and Manufactures (1727) which was mainly composed of aristocrats, members of the bar and of the Lowland gentry. ${ }^{28}$ The expansion of the textile industry and the flourishing droving trade in cattle provided additional sources of income for the estates.

New agricultural techniques helped landowners to enrich themselves. As shown by the records of the factor of the Hamilton estate, John Burrell, in the $1760 \mathrm{~s}$, rents in kind gave way to rents in money, single tenancies replaced multiple tenancies and enclosure appeared on the Hamilton

25. Lord John Hamilton was the director of the Scottish Trading Company created in 1695 and was among those responsable for the failure of the Darien scheme. He wrote: "Husbandry inlarges a Country, and makes it as if ye had conquered another Country adjacent thereto; And I am sure, a Conqueror by the Spade and the Plough, is both more just and of longer Continuance, than what is got by Sword and Bow." John Hamilton, Lord Belhaven, The Countrey-Man's Rudiments: Or, An Advice to the Farmers in East-Lothian, How to Labour and Improve Their Ground, Edinburgh, Printed by the heirs and successors of Andrew Anderson, 1699, p. 5.

26. "The late John Cockburn of Ormistown, promoted emulation and industry among his people. His patriotic zeal was rewarded: he lived to see his estate in a higher degree of cultivation, than even to this day is seen in any other part of Scotland ..." Lord Kames, The Gentleman Farmer. Being an Attempt to Improve Agriculture by Subjecting It to the Test of Rational Principles, Edinburgh, Printed for W. Creech, London, T. Cadell, 1776, p. xi. John Cockburn was a great improver as show his Letters to His Gardener from 1727 to 1744, ed. James Colville, Edinburgh, Scottish Historical Society, 1904.

27. Henry Hamilton (ed.), Selections from the Monymusk Papers, 1713-1755, Edinburgh, Scottish History Society, 1945, p. 151.

28. The Bounty Act (1742) stimulated commerce between the Clyde and the American colonies thanks to a system of export grants. William Ferguson, Scotland: 1689 to the Present, Edinburgh, Oliver \& Boyd, 1968, p. 79. With their investment, the tobacco traders participated in the expansion of textile manufacture and mining industry. T. M. Devine, "The Colonial Trades and Industrial Investment in Scotland, c. 1700-1815", The Economic History Review, new ser. 29.1, 1976, pp. 1-13. 
lands at Kinneil in the aftermath of the Jacobite rebellion. ${ }^{29}$ John Burrell looked to maximise profits by increasing rents through improvements, and between 1764 and 1769 , rents doubled. It is symptomatic that the Scottish Lowlands, a fertile region, were where remarkable country houses flourished - the earl of Haddington's Mellerstain House, the earl of Cassilis's Culzean Castle, the earl of Hopetoun's Hopetoun House, the duke of Buccleuch's Dalkeith Palace or the marquess of Tweeddale's Yester House. The Palladian villas which were built from the 1720s were not only designed as beautiful places for leisure but were set in productive landscapes. The house was the centre of agricultural activity and the cost of the lifestyle was to be supported by the estate as much as possible. John Reid (1656-1723), a Scottish botanist, gave the following advice to his fellow countrymen in 1683: "Situate your House in a healthy Soil, near to a fresh Spring, defended from the impetuous West Winds, Northern Colds, and Eastern Blasts: And mind Regularity." ${ }^{30}$ Like many other landowners, Sir John Clerk of Penicuik, a member of the Society of Improvers, followed this advice when he built his villa Mavisbank, outside Edinburgh, in the 1720s.

The improvement of a great estate initially came at a cost for it provided an increased profit only through a long-term investment. The cost of materials and labour were often alluded to in the family archives. A professional manager was often brought in to manage the estate. While enclosure eventually allowed for the farms to be let at higher rates, the construction of walls and ditches was expensive at first. At Yester, an "Estimate for inclosing and fencing the moss at quarry ford with a five foot ditch planted with thorns or beech" amounted to $£, 55$ in $1798 .{ }^{31} \mathrm{In}$ his survey of the Hamilton estate, John Burrell concluded that an investment of $£ 4,569$ would be necessary and this corresponded to over four years of extra profit. ${ }^{32}$ Even though afforestation added to the aesthetics of estates it only brought returns after several generations when wood became mature and profit could be reaped from commercial forestry, such as at Blair Atholl, the property of the duke of Atholl, Inveraray, the estate of the duke of Argyll, or Bowhill which belonged to the duke of Buccleuch. ${ }^{33}$ Therefore, the cost of improvement shows that land alone

29. Tom Devine, The Transformation of Rural Scotland: Social Change and the Agrarian Economy, 16601815, Edinburgh, Edinburgh UP, 1994, p. 97.

30. John Reid, The Scots Gard'ner in Two Parts. The First for Contriving and Planting Gardens, Orchards, Avenues and Groves, 1683, Edinburgh, John Moncur, 1721, p. 2.

31. NLS MS 14694/126.

32. Tom Devine, op. cit., p. 100.

33. At Blair Atholl, James Murray (c. 1690-1764), second duke of Atholl, planted a variety of trees and his forestry was extended by his successors. The fourth duke of Atholl (1755-1830) who 
was not enough to support the costs of extensive schemes for the houses and an expensive lifestyle. At Yester, what little profit was reaped from the land was invested into the house and landscape, which proves that estates were thought of in terms of exploitation. A bill of account of Charles Hay of Yester of 1750 lists the amount that the Tweeddale family owed for furniture bought for Pinkie, Yester and Edinburgh. The total of the bill is of $£ 650$. On the opposite side of the account is a pencilled note which states "by 7 years rent of the Pinkie park, viz compts 1743, 1744, 1745, 1746, 1747, 1748 and 1749 payable at Candlemass and Lambas immediately following the cropt, at £50 per annum, totalling E650." 34 The remaining three hundred pounds was also financed directly from the estate, however not from agricultural revenues: "By 3 years tack duty of the Pinkie coal from Michelmas 1747 of which is settled by my lord Marques's letter of 1st Oct. 1750 to be the time for the coal duty commencing to Michaelmas 1750 at £100 per annum, total £300." "35 Improved agriculture participated in financing the house but other resources were necessary to cover expenditure.

One other way of using the landscape was to exploit the mineral resources through mining and quarrying. William Adam exploited the coal of the fifth duke of Hamilton (1703-43) at Bo'ness while he remodelled Hamilton Palace and built the hunting lodge of Chatelherault in the $1730 \mathrm{~s}-1740 \mathrm{~s}$. The duke used his mines as a way to finance architecture. The coal on the lands of Pinkie, outside Musselburgh, was also leased to William Adam and its profit was used to finance Yester, another house of the Tweeddale family. The Clerks of Penicuik made money from their coal mine at Loanhead, which was used to finance the building of Penicuik and Mavisbank. The earl of Hopetoun at Leadhills and the duke of Queensberry at Wanlockhead extracted lead. ${ }^{36}$ Paradoxically, the necessity for increased capital to finance the estate and lifestyle pushed landowners to exploit resources extensively, sometimes at the expense of their houses. With the development of the mining industry around Pinkie, the estate became used as a commercial venture and John Adam could not

\footnotetext{
continued planting after 1744 was dubbed the "Planting duke". Peter Verney, The Gardens of Scotland, London, B. T. Batsford LTD, 1976, p. 50. The ambition of landowners could be felt by Gilpin who wrote after a visit at Inveraray in 1776: "The duke [of Argyll] was the greatest connoisseur in trees of any man in England; and naturalized great numbers. He piqued himself on having his trees in the greatest perfection. If a tree did not immediately thrive, he never waited for its growth, but put in another." William Gilpin, Observations Relative Chiefly to Picturesque, Made in the Year 1776, on Several Parts of Great Britain; Particularly the High-Land of Scotland, vol. II, London, Printed for R. Blamire, Strand, 1789, p. 192.

34. NLS MS 14551/119.

35. NLS MS $14551 / 119$.

36. William Fraser, The Scotts of Buccleuch, vol. I, Edinburgh, n.p., 1878, p. 522.
} 
fail to notice by the 1750s: "several little cracks or crevices in the side walls of the house at Pinkie." 37 Pinkie was eventually abandoned by the Tweeddale family in the early nineteenth century whilst the palace of Hamilton was destroyed due to the mining developments of the estate.

Trade and commerce with the colonies also brought considerable wealth which initiated social change as some relatively nouveaux riches became Scotland's richest men. Capital from the empire as a result of major trade expansion, especially after the 1730s, stimulated agricultural, commercial and architectural developments in Scotland. ${ }^{38}$ Colonial money allowed the surge in building on the outskirts of Glasgow, the premier Scottish trading port in the 1770s, and in the western part of Scotland. Slave, tobacco and sugar traders who controlled colonial trades had houses built because they desired a more ceremonious style of living and because land was a testament to their social status. Daniel Campbell of Shawfield (1670-1753), a successful merchant who made a fortune in the tobacco and slave trade, was among the first to participate in the building of these new houses. On his estate of Shawfield to the east of Glasgow he built a fine mansion house in the Palladian style in 1711 after a design by Colen Campbell, his kinsman and the author of Vitruvius Britannicus $(1715,1717)$. This compact villa in the classical style set the pattern for other houses, like that of the wealthy Tobacco Lord George Buchanan who erected his mansion in Virginia Street in 1752 and which seems to have been modelled on Shawfield mansion, albeit in a smaller size. John Glassford, who had made a fortune trading with the Americas, was the second owner of the Shawfield mansion, which he occupied until his death in 1783. Some families, other than specifically merchant ones, reaped significant profit from commerce, like the Hamiltons.

The extension of credit through national and provincial banks provided additional revenues for the estates. Resorting to credit became more common in the eighteenth century because the resources of the estates were insufficient to cover the building expenses of large country houses. ${ }^{39}$ In the eighteenth century it was relatively easy for families of ducal or

\section{NLS MS 14429/229.}

38. Some recent research has focused on the importance of repatriated capital from the empire. John M. MacKenzie and T. M. Devine (eds), Scotland and the British Empire, Oxford, Oxford UP, 2011. Michael Fry, The Scottish Empire, East Linton, Tuckwell Press, Edinburgh, Birlinn, 2001. Stuart Nisbet, The Rise of the Cotton Factory in Eighteenth-Century Renfrewshire, Oxford, Archaeopress, 2008. Steve Murdoch and A. Mackillop (eds), Fighting for Identity: Scottish Military Experience c. 1550-1900, Leiden, Brill, 2002. Steve Murdoch and A. Mackillop (eds), Military Governors and Imperial Frontiers c. 1600-1800: A Study of Scotland and Empires, Leiden, Boston, Brill, 2003. Allan I. Macinnes, Union and Empire, The Making of the United Kingdom in 1707, Cambridge, Cambridge UP, 2007.

39. For details on the indebtedness of the aristocracy, see: David Cannadine, "Aristocratic Indebtedness in the Nineteenth Century: The Case Reopened", Economic History Review, 30, 1977, pp. 624-50 
peerage rank to have access to credit which was commonly used to fund houses with extensive parks and gardens. From the 1770s the estates in Scotland provided safe securities, hence the easy access to credit of their owners. ${ }^{40}$ The second duke of Argyll (1678-1743) and his brother the earl of Islay (1682-1761) had important financial interests in the Royal Bank of Scotland (1727), which allowed them to control the resources of the country and carry out numerous innovations at Inveraray. The Bank of Scotland and the Board of Trustees for Fisheries and Manufactures were part of the patronage system devised by the Argylls and controlled by their agent in Scotland, Lord Milton. Public investments in favour of improvement therefore paralleled private ones and quite often public money was channelled to the third duke's private investments, such as the spinning industry. ${ }^{41}$ As part of his improvement programme on his estate of Inveraray in the Highlands, the duke built a completely new castle to symbolize his status and to assert his pro-Hanoverian commitment. He planned a new town in a cruciform layout after a design by John Adam in the 1750s. The town which was dedicated to industry shows how the duke and other landowners gradually distanced themselves from the rural communities in the second half of the eighteenth century. The duke fostered clearances on his lands.

Another source of income for the estate was that which could be gained from pensions and political posts, although such subsidies were not always remotely paid on time. As with the indebtedness of the aristocracy it is difficut to establish the income that could be gained from the various political posts. However it is clear that high levels of income could be gathered by those holding the highest posts. Supporting the Hanover dynasty gave access to posts and sinecures - often for life - and many Scots combined several functions at once. According to a 1705 list establishing the value of sinecures kept in the Tweeddale family archives, the Chancellor perceived over $£ 1,655$ a year, the President of the Privy Council, the Keeper of the Privy Seal, the Secretary of State $£ 1,000$ each, the Lord Advocate $£ 600$, the Master of Works $£ 300$ whilst the Keeper of the Signet was paid $£ 100$ - ten to thirty times as much as a craftsman. ${ }^{42}$ In the Edinburgh Almanack of 1755, most of the salaries were twice as much as a century before (in 1705). ${ }^{43}$ In 1755, the duke of

and John Habbakuk, "The Rise and Fall of English Landed Families", Transactions of the Royal Historical Society, Fifth Series, 29, 1979, pp. 187-207.

40. Cannadine, op. cit., p. 635.

41. John Stuart Shaw, The Management of Scottish Society, 1707-1764, Power, Nobles, Lawyers, Edinburgh Agents and English Influences, Edinburgh, Donald, 1983, p. 141.

42. NLS MS 14498/28.

43. Edinburgh Almanack, Edinburgh, Printed by R. Fleming, 1755, p. 25, p. 27, p. 29. 
Argyll, a Keeper of the Privy Seal, and the duke of Atholl, a Lord Privy Seal, were paid £3,000 each. As a Lord Advocate, Robert Dundas of Arniston received $£ 1,000$ and his cousin, Charles Erskine of Tinwald, then Lord Justice Clerk, £500. Arniston House, in Midlothian, and Tinwald House, in Dumfriesshire, were two houses where the Adam family was involved from the 1730 s and Arniston was decorated with rich plasterwork. Having access to a political post allowed landowners to indulge in architectural pursuits. The patrons of William Adam and his sons were often judges, like Lord Dun, Lord Milton or Lord Minto. During his lifetime, the second duke of Argyll was a Commissioner in the last Scottish parliament, a Commander-in-Chief of the Forces in Scotland, a Master-General of the Ordnance, a High Steward of the Household and a Commander-in-Chief of the British Forces. In the 1740s, the duke could easily buy Royston house, a house situated outside Edinburgh which he renamed Caroline Park, and finance the works done by the architect William Adam. His brother, the third duke of Argyll (the earl of Ilay before 1743), acted simultaneously as Keeper of the Great Seal $(£ 3,000)$ and as Lord Justice General $(£ 2,000)$ for almost thirty years. He thus gained at least $£ 5,000$ a year. ${ }^{44}$ These functions allowed him to pursue large-scale agricultural, economic and social reforms at Inveraray. Works at Yester house, which started in 1729, accelerated when its owner, the fourth Marquess of Tweeddale, became Secretary of State for Scotland in 1742. On the contrary, during the period when the marquess failed to be reelected in the House of Lords - from 1734 to 1742 - work on the house slowed down and the interior decoration remained scarce. After 1742 and despite the cost of maintaining a London household, the Secretary of State for Scotland could change the facade of Yester and finance the decoration of the state apartments. Although the large estate of Hamilton could finance the works done by William Adam at Hamilton Palace and at Chatelherault, the hunting lodge of the duke, between 1727 and 1742, these works coincided with the duke joining the cause of the Hanovers in 1726. The duke became Lord of the Bedchamber of George II in 1727. A new post thus meant additional revenues which could help repay a loan, a mortgage or finance the building of a house.

Country houses were thus places of expense and taste and were essential to assert one's social status. The money to finance them came from a variety of sources. The powerful and wealthy Scottish elite exploited the

44. The third duke of Argyll was Lord Justice General from 1710 to 1761 and Lord Keeper of the Great Seal from 1733 to 1761. He was Lord Keeper of the Privy Seal between 1721 and 1733. Besides, he was Lord Clerk Register between 1714 and 1716. 
resources of their lands to support a lifestyle of luxury. In some instances modernisations were fostered by this need for cash to support the household, but in others they put a drastic strain on the estates and seriously endangered them. With the rise in the market economy, a new logic of exploiting the land replaced the feudal ties that linked landowners to the people on their lands. Improved land provided agricultural resources, timber, coal or stone. These materials could be used on the estate or sold on the market. Although the activities on the estates presupposed costly investments, rising food prices, the need for cash and the general prospect of improvement enticed many Scottish landowners to foster new activities. By the 1760s and 1780s great transformations were under way in Scotland and in estates in particular. Land was not the only resource necessary to finance a lifestyle of luxury. The coal and textile industries, as well as the extension of credit through national and provincial banks, played a significant role in the expansion of aristocratic capital. Commerce with the colonies, and with it the bounties and prizes gained in the army and navy, as Scotland was fully participating in the expansion of the British empire, provided additional revenues and allowed merchants to invest in mansion building, primarily on the west coast. Loans and political posts appeared essential to develop a great house and its pleasure landscape. By the eighteenth century the aristocracy had to borrow money for the creation of houses and landscapes. For large families, especially those with ducal or peerage incomes, access to credit was relatively easy since estates were acceptable sources of security from the 1770 s. Combined with the income from the estate, these revenues provided the necessary capital for the creation of a large country house. The variety of resources to which landowners had access in the eighteenth century was favourable to mansion house building. It also testified to the landowners' gradual distancing of themselves from the traditional modes of funding and to their interest in activities with high returns on capital.

\section{Bibliography}

\section{Archives}

National Archives of Scotland (NAS) GD28/427. GD45/17/769.

National Library of Scotland (NLS) MS 14429/229. MS 14498/28. MS 14551/57, 59, 119. MS 14666/1. MS 14694/126. 


\section{Articles in a journal}

Cannadine David, "Aristocratic Indebtedness in the Nineteenth Century: The Case Reopened", Economic History Review, 30, no. 4, 1977, pp. 62450.

Eustace Katharine, "Robert Adam, Charles-Louis Clérisseau, Michael Rysbrack and the Hopetoun chimneypiece", The Burlington Magazine, no. 1136, Nov. 1997, pp. 743-52.

HaвbakuK John, "The Rise and Fall of English Landed Families", Transactions of the Royal Historical Society, Fifth Series, no. 29, 1979, pp. 187207.

\section{Works}

ADAm William, Vitruvius Scoticus, Edinburgh, P. Harris, 1980 [1812].

Campbell Colen, Vitruvius Britannicus, Or the British Architect, Containing the Plans, Elevations, and Sections of the Regular Buildings, Both Publick and Private, in Great Britain, 2 vols, London, John Nicholson, 1717.

Cockburn John, Letters to His Gardener from 1727 to 1744, ed. James Colville, Edinburgh, Scottish Historical Society, 1904.

Defoe Daniel, A Tour Thro' the Whole Island of Great Britain. Divided into Circuits or Fourneys. Giving a Particular and Entertaining Account of Whatever Is Curious, and Worth Observation, vol. IV, 1724, London, Printed for S. Birt, 1748.

Devine Tom, The Transformation of Rural Scotland: Social Change and the Agrarian Economy, 1660-1815, Edinburgh, Edinburgh UP, 1994.

Dunbar John G., The Historic Architecture of Scotland, London, Batsford, 1966.

Edinburgh Almanack, Edinburgh, Printed by R. Fleming, 1755.

FErguson William, Scotland: 1689 to the Present, Edinburgh, Oliver \& Boyd, 1968.

Fraser Sir William, The Scotts of Buccleuch, vol. I, Edinburgh, n.p., 1878.

FRY Michael, The Scottish Empire, Edinburgh, Birlinn, 2001.

Gilpin William, Observations Relative Chiefly to Picturesque, Made in the Year 1776, on Several Parts of Great Britain; Particularly the High-Land of Scotland, vol. II, London, Printed for R. Blamire, Strand, 1789.

Glendinning Miles, Macinnes Ranald, Mackechnie Aonghus (eds.), Building a Nation: The Story of Scotland's Architecture, Edinburgh, Canongate, 1999.

Hamilton Henry (ed.), Selections from the Monymusk Papers, 1713-1755, Edinburgh, Scottish History Society, 1945.

Hamilton John, Lord Belhaven, The Countrey-Man's Rudiments: Or, An Advice to the Farmers in East-Lothian, How to Labour and Improve Their Ground, 
Edinburgh, Printed by the heirs and successors of Andrew Anderson, 1699.

Home Henry, Lord Kames, The Gentleman Farmer. Being an Attempt to Improve Agriculture by Subjecting It to the Test of Rational Principles, Edinburgh, Printed for W. Creech, London, T. Cadell, 1776.

Hume of Crossrig, Sir David, A Diary of the Proceedings in the Parliament and Privy Council of Scotland, 21 May 1700-7 March 1707, Edinburgh, Bannantyne Club, 1828.

Lukowski Jerzy, The European Nobility in the Eighteenth Century, Basingstoke, Palgrave Macmillan, 2003.

LeTtice John, Letters on a Tour Through Various Parts of Scotland in the Year 1792, London, T. Cadell, 1794.

Lynch Michael, Scotland: A New History, London, Barrie \& Jenkins, 1991.

Macinnes Allan I., Union and Empire, The Making of the United Kingdom in 1707, Cambridge, Cambridge UP, 2007.

Mackenzie John M., Devine T. M. (eds), Scotland and the British Empire, Oxford, Oxford UP, 2011.

MAcKy John, A Journey through Scotland. In Familiar Letters from a Gentleman Here, to His Friend Abroad. Being the Third Volume Which Compleats Great Britain. By the Author of The Fourney thro' England, London, J. Pemberton \&J. Hooke, 1723.

Millar Alexander H., The Book of Record. A Diary Written by Patrick, First Earl of Strathmore, and Other Documents Relating to Glamis Castle, 1684-1689, vol. IX, Edinburgh, Scottish History Society, 1890.

Murdoch Steve, Mackillop A. (eds), Fighting for Identity: Scottish Military Experience c. 1550-1900, Leiden, Brill, 2002.

-, Military Governors and Imperial Frontiers c. 1600-1800: A Study of Scotland and Empires, Boston, Brill, 2003.

Nisbet Stuart, The Rise of the Cotton Factory in Eighteenth-Century Renfreweshire, Oxford, Archaeopress, 2008.

Pennant Thomas, A Tour in Scotland and Voyage to the Hebrides, vol. I, 1772, London, Benjamin White, 1776.

ReID John, The Scots Gard'ner in Two Parts. The First for Contriving and Planting Gardens, Orchards, Avenues and Groves, 1683, Edinburgh, John Moncur, 1721.

SHaw John Stuart, The Management of Scottish Society, 1707-1764, Power, Nobles, Lawyers, Edinburgh Agents and English Influences, Edinburgh, Donald, 1983.

SLEzer John, Theatrum Scotiae: Containing the Prospects of Their Majesties Castles and Palace; Together with Those of the Most Considerable Towns and Colleges; The Ruins of Many Ancient Abbeys, Churches, Monasteries and Convents, Within the Said Kingdom. All Curiously Engraven on Copper Plates. With a Short Descrip- 
FINANCING THE COST OF AN EIGHTEENTH-CENTURY SCOTTISH ESTATE

tion of Each Place, London: Printed by John Leake for Abell Swalle, 1693.

Verney Peter, The Gardens of Scotland, London, B. T. Batsford LTD, 1976. Wordsworth William, The Poetical Works of William Wordsworth, vol. V, London, Edward Moxon, 1837. 